\title{
Applied electro-optics educational and training program with multiple entrance and exit pathways
}

Patricia Scott, Feng Zhou, Dorothy Zilic

Patricia Scott, Feng Zhou, Dorothy Zilic, "Applied electro-optics educational and training program with multiple entrance and exit pathways," Proc. SPIE 9665, Tenth International Topical Meeting on Education and Training in Optics and Photonics, 966506 (3 June 2007); doi: 10.1117/12.2207559

SPIE Event: Tenth International Topical Meeting on Education and Training in Optics and Photonics, 2007, Ottawa, Ontario, Canada 


\title{
Applied Electro-Optics Educational and Training Program with Multiple Entrance and Exit Pathways
}

\author{
Patricia Scott, Ph.D., Feng Zhou, Ph.D., and Dorothy Zilic, M.S. \\ Indiana University of Pennsylvania, Northpointe Regional Campus, \\ 167 Northpointe Boulevard, Freeport, PA 16229; Phone: 724-294-3300; E-mail: dzilic@iup.edu
}

\begin{abstract}
This paper presents an innovative hands-on training program designed to create a pipeline of highly-skilled technical workers for today's workforce economy. The 2+2+2 Pennsylvania Integrated Workforce Leadership Program in Electro-Optics prepares students for a career in this new high-tech field. With seamless transition from high school into college, the program offers the versatility of multiple entrance and exit pathways. After completion of each educational level, students can exit the program with various skill levels, including certificates, an associate's degree, or a bachelor's degree. Launched by Indiana University of Pennsylvania (IUP) in partnership with Lenape Vocational School (Lenape), the $2+2+2$ educational pathway program was implemented to promote early training of high-school students. During the first level, students in their junior and/or senior year enroll in four Electro-Optics courses at Lenape. Upon completion of these courses and an Advanced Placement Equivalency course with an appropriate exam score, students can earn a certificate from Lenape for the $15+$ credits, which also can be articulated into IUP's associate degree program in Electro-Optics. During the second level, students can earn an associate's degree in Electro-Optics, offered only at the IUP Northpointe Campus. After completion of the Associate in Applied Science (A.A.S.), students are prepared to enter the workforce as senior technicians. During the third level, students who have completed the Associate of Science (A.S.) in Electro-Optics have the opportunity to matriculate at IUP's Indiana Campus to earn a Bachelor of Science (B.S.) degree in Applied Physics with a track in Electro-Optics. Hence, the name $2+2+2$ refers to getting started in high school, continuing the educational experience with an associate's degree program, and optionally moving on to a bachelor's degree. Consequently, students move from one educational level to the next with advanced credits toward the next degree. This program was made possible by two grants from the Pennsylvania Department of Community and Economic Development (PA DCED). The intent of the grant is to foster partnerships that will develop programs in high-tech fields, such as biotechnology/life sciences, information technology, opto-electronics, and advanced manufacturing and materials. Topics of discussion will include program development, curriculum development, course descriptions, course sequencing, outreach and recruitment efforts, and program challenges.
\end{abstract}

\section{Introduction}

The $2+2+2$ Workforce Leadership Grant Program (WLGP) was designed to establish unified curriculum across two-year vocational programs and two- and four-year post-secondary educational programs in information technology, biotechnology, and advanced manufacturing career clusters. Administered through the Pennsylvania Department of Community and Economic Development (DCED), the program provides funding to high schools as well as colleges and universities to help them prepare high-technology programs where students can continue their education by using credits earned in advance toward their next degree. With a seamless transition from the secondary school into college, the program offers students the versatility of multiple entrance and exit points. After completion of each educational level, students can exit the program with various skill levels including certificates, an associate's degree, or a bachelor's degree.

Established in January 2003, the 2+2+2 WLGP fosters the development of school, community college, university, and business partnerships that will ensure that Pennsylvania emerges as a national leader in the development of industry-focused partnerships that will train a workforce capable of competing in the global economy.

Indiana University of Pennsylvania (IUP) received $\$ 200,000$ in 2005-2006 to establish a $2+2+2$ Workforce Leadership Program in Electro-Optics in Armstrong County. With the financial assistance from the DCED, IUP partnered with Lenape Technical School and all four school districts in Armstrong County: Apollo-Ridge, 
Armstrong, Freeport, and Leechburg. The program established integrated and seamless curriculum development that was designed to support education and training, beginning in high school/vocational technical school, progressing to a two-year degree, and culminating in a four-year degree in the emerging field of Electro-Optics. As the lead institution, IUP provides collaboration among the partners by establishing curriculum design and program implementation in addition to preparing the articulation agreement that will be used for transferring credits. The university also works closely with the regional Electro-Optics industry to facilitate job opportunities for students when they graduate from the program.

Typically applicants for the $2+2+2$ WLGP include a career/technical school, a two-year community college, and a four-year institution. However, in this instance IUP serves both as the two-year and four-year components as it offers a two-year degree program in Electro-Optics only at its Northpointe Regional Campus in Freeport, PA, and a four-year degree in Applied Physics with a track in Electro-Optics at its Main Campus in Indiana, PA. The regional campus is a recently built state-of-the-art, commuter campus located approximately 38 miles southwest of Indiana. It is located immediately off Route 28 at Exit 18 just 35 minutes from downtown Pittsburgh.

The program was designed so students could enter IUP from one of the seven sending high schools from the four school districts or from Lenape, which is a comprehensive career technical school.

In Fall 2002, IUP introduced a two-year Associate's Degree in Electro-Optics. The program was established by faculty members from the Physics Department who traveled to other colleges and universities that offered comprehensive Electro-Optics programs designed for industry. They took the best practices from the programs that they visited and developed a hands-on training program that would create a pipeline of highly-skilled technical workers for this new industry. Once the curriculum was in place, administrators at IUP sought the input of local Electro-Optics leaders. The curriculum was presented to the Chief Executive Officers of area Electro-Optics corporations and members of the Electro-Optics Alliance (EOA) for their review and suggestions. The EOA is comprised of industrial, academic, and government affiliates. It is a component of the Penn State Electro-Optics Center (EOC), a manufacturing center of excellence sponsored by the U.S. Navy Manufacturing Technology (MANTECH) Program and the Office of Naval Research. It is located in the same Technology Park as the IUP Northpointe Regional Campus, and it also serves as an industry partner for the $2+2+2$ WLGP in Electro-Optics. The EOC plays a vital role in advancing Electro-Optics capabilities nationally, while advancing local economic opportunities in Armstrong County. Companies moving into the area can tap into the center's expertise, finding not only technical support but educational advantages.

Concurrent with IUP's Electro-Optics degree program development, Lenape developed two Electro-Optics courses for its Adult Evening Program. These courses were developed to prepare displaced workers for entry-level positions in this new high-tech industry. The intent was that the IUP and Lenape initiatives would support each other. However, there was no academic connection or partnership between the Lenape courses and the IUP degree program until the $2+2+2$ WLGP was established. The grant allowed IUP to work with Lenape to create four entrylevel Electro-Optics courses that would articulate into IUP's two-year degree program.

Funding from the grant allowed IUP and Lenape to offer release time to their faculty so they could work on curriculum and outcomes assessment for the new industry-focused program. Four courses were developed for articulation into IUP's program: EOPT 125-Introduction to Electronics (4 credits); EOPT 105-Computer Interfacing ( 3 credits); EOPT 110-Geometric Optics (3 credits); and PHYS 100-Prelude to Physics (3 credits). Students completing these courses with a $\mathrm{C}$ grade or above can transfer 13 credits into IUP's two-year degree program. If they also complete an Advanced Placement (AP) Equivalency course with the appropriate exam score (3), they can transfer 15+ credits toward the Associate's Degree in Electro-Optics, permitting them to earn one semester of college credits while they are still in secondary school as stipulated by the grant. This provides students with a substantial savings as they can complete one semester of college for free.

For many years Armstrong County thrived economically on such industries as brick, coal, and steel. However, in recent decades the emphasis on these industries has shifted, resulting in an economic decline and a demographic shift for this once prosperous region. In order to survive, this proud county had to undergo a paradigm shift and had to focus its attention on the revitalization of its economy and workplace. To accomplish these goals, the county has attracted a new high-tech industry-Electro-Optics—-to the area. According to regional industry officials, 
technology industry sectors are key drivers of a region's economic growth. The $2+2+2$ WLGP has provided IUP with the financial resources to create a workforce pipeline with multiple pathways for this new industry.

The objectives of the grant included:

- Design and establish an integrated industry curriculum with our partners

- Articulate a minimum of 15 credits from the secondary schools and Lenape into the Associate's Degree

- Articulate 63 credits from the Associate's Degree into the Bachelor's Degree

- Create and distribute career and marketing materials to recruit 15-20 students into the Lenape program

- Provide academic advisement to students to insure that all of the required coursework is taken in sequence

- Provide a summer Electro-Optics experience for students

- Familiarize students with Nanofabrication

- Create a 2+2+2 WGLP Electro-Optics Steering Committee

IUP and its partners accomplished their goals, and eighteen students were recruited into the program at Lenape for the Fall 2006 school year. In 2006-2007, IUP received an Extension Grant for \$160,000 from the DCED to continue to further develop its Electro-Optics program in collaboration with its partners. The university has applied for a second Expansion Grant that would permit it to take its prototype program to Westmoreland County, a county that borders Armstrong County and is located approximately 20 minutes from the Northpointe Regional Campus.

\section{2+2+2 Educational Pathway}

The $2+2+2$ WLGP provides considerable flexibility with multiple entrance and exit points for students to pursue vocational training and academic education in Electro-Optics, as shown in Figure 1.

The first level of the $2+2+2$ WLGP provides students with the opportunity to enter the program at the beginning of their junior year in high school. During their junior and senior years, students co-enroll in the appropriate math and science courses and four Electro-Optics courses offered at Lenape. The four courses are: Prelude to Physics (PHYS 100), Computer Interfacing (EOPT 105), Geometric Optics (EOPT 110) and Introduction to Electronics (EOPT 125). A faculty member at IUP who serves as the coordinator of the program received release time to align the Lenape courses with the courses offered by IUP. Upon completion of the Lenape courses and an AP Equivalency course with the appropriate exam score, students can earn a certificate for the 15+ credits which can be articulated into IUP's Associate's Degree Program in Electro-Optics. Students may exit the program at this point with a Certificate from Lenape. The training received during this phase of the program prepares students for entrylevel technical positions in the Optics. At this point, they have the option of going directly into industry or to continue on to the second level.

Figure 1: $2+2+2$ Educational Pathway

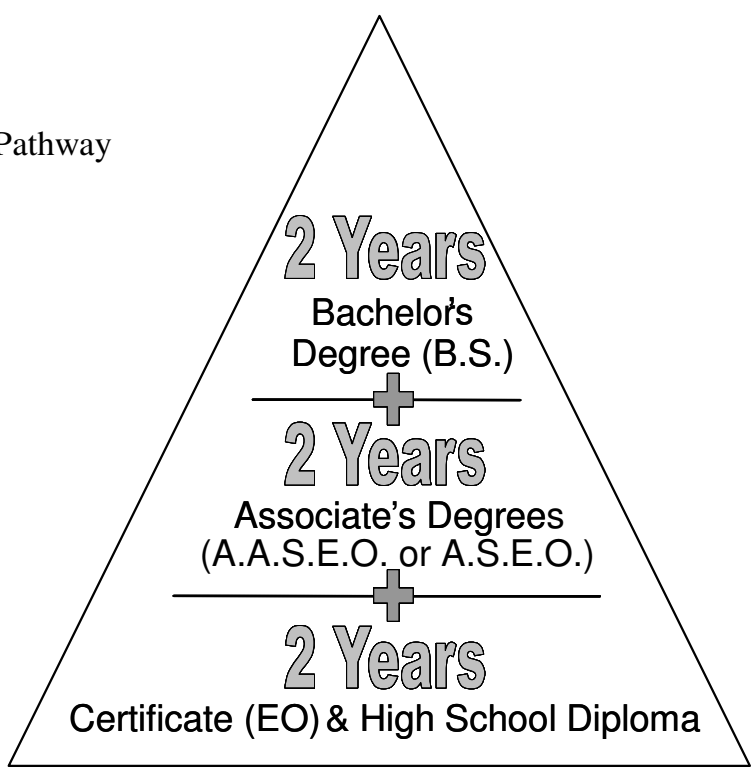


The second level of the $2+2+2$ Program involves coursework offered by the Physics Department at IUP's stateof-the-art facility at the Northpointe Regional Campus. Students have the option of earning a Certificate in ElectroOptics from IUP by completing an additional fifteen credits of specified optics courses. Students may exit at this juncture or they may complete either an Associate in Applied Science in Electro-Optics (A.A.S.E.O.) or an Associate in Science in Electro-Optics (A.S.E.O). After completing the A.A.S.E.O degree, students are prepared to move into senior technical positions in the industry. Students may exit the $2+2+2$ Program at this point or continue to the third level.

The third level of the 2+2+2 Program takes place at IUP's Main Campus in Indiana, PA. Students who have completed coursework for the A.S.E.O. have the opportunity to matriculate at IUP's campus in Indiana by transferring 63 credits toward a Bachelor of Science degree in Applied Physics/Electro-Optics Track. After completing this third level, students can enter the workforce into highly skilled positions in the field.

The Electro-Optics Industry is expected to grow from a $\$ 34$ billion industry today to a $\$ 500$ billion industry by 2010. The demand for workers in this field, especially at the technician level, has been acute and many companies will be offering finders' fees for Electro-Optics technicians.

\section{Core Courses}

IUP has collaborated with several local Photonics companies to gain a better understanding of their current staffing needs. Based on feedback from these companies, nine courses were developed for IUP's program. These courses provide students with the necessary background to move into related positions in Optics. The nine core courses for IUP's program are listed and outlined in Table 1.

Table 1: EO Program Core Courses

\begin{tabular}{|c|c|c|}
\hline Number & $\begin{array}{l}\text { IUP Course Title } \\
\text { and Number }\end{array}$ & Course Description \\
\hline 1 & $\begin{array}{l}\text { Computer } \\
\text { Interfacing in } \\
\text { Electro-Optics } \\
\text { (EOPT 105) }\end{array}$ & $\begin{array}{l}\text { The first half of the course introduces the student to basic digital } \\
\text { electronics and teaches them how computers interface with the outside } \\
\text { world. These concepts are applied in the second half of the course. The } \\
\text { Labview programming environment is used to collect experimental data } \\
\text { and to control scientific instruments. The course assumes a basic } \\
\text { background in electronics (equivalent to an introductory course, such as } \\
\text { EOPT 125) and computers (windows environment, word processor and } \\
\text { spreadsheet use) as well as knowledge of algebra. }\end{array}$ \\
\hline 2 & $\begin{array}{l}\text { Introduction to } \\
\text { Electronics } \\
\text { (EOPT 125) }\end{array}$ & $\begin{array}{l}\text { This course is intended to be an introductory course requiring a } \\
\text { minimum knowledge of mathematics. The course covers DC and AC } \\
\text { circuits, resistors, capacitors, inductors, filters, diodes, power supplies, } \\
\text { transistors, and operational amplifiers. Emphasis is be placed on both } \\
\text { the principles and the "rules of thumb" used in everyday laboratory } \\
\text { settings. A laboratory component is included in this course so students } \\
\text { can gain practical experience in building electronic circuits and using } \\
\text { electrical measuring devices with an eye toward lab applications. }\end{array}$ \\
\hline 3 & $\begin{array}{c}\text { Geometric Optics } \\
\text { (EOPT 110) }\end{array}$ & $\begin{array}{l}\text { Introduces the student to the principles and theory of light as a } \\
\text { geometrical ray and gives an elementary treatment of image formation. } \\
\text { This course will cover selected topics including reflection, refraction, } \\
\text { optical components, optical instruments, and optical system design and } \\
\text { evaluation. Students will learn how to apply matrix optics and the } \\
\text { optical design software ZEMAX to simple optical components. }\end{array}$ \\
\hline 4 & $\begin{array}{l}\text { Wave Optics } \\
\text { (EOPT 120) }\end{array}$ & $\begin{array}{l}\text { Introduces the student to the principles of light as an electromagnetic } \\
\text { wave and provides elementary treatments of light sources and important } \\
\text { wave phenomena. The theory is applied to common devices used in the } \\
\text { photonics field. Topics include properties of light, reflection, refraction, } \\
\text { absorption and transmission, interference, diffraction, polarization, and } \\
\text { holography. }\end{array}$ \\
\hline
\end{tabular}




\begin{tabular}{|c|c|c|}
\hline 5 & $\begin{array}{l}\text { Detection and } \\
\text { Measurement } \\
\text { (EOPT 210) }\end{array}$ & $\begin{array}{l}\text { Introduces the student to the technology and techniques involved in } \\
\text { making electro-optical measurements. Students will learn the basic } \\
\text { theory and working mechanisms of optical detectors, interferometers, } \\
\text { spectrometers, and imaging devices, as well as the optical components } \\
\text { used along with these instruments. }\end{array}$ \\
\hline 6 & $\begin{array}{l}\text { Introduction to } \\
\text { Lasers } \\
\text { (EOPT 220) }\end{array}$ & $\begin{array}{l}\text { Introduces the student to laser safety practices, basic laser physics, and } \\
\text { measurements of laser properties such as divergence, mode spacings, } \\
\text { polarization, and power. The student will align various laser cavities and } \\
\text { be exposed to several CW lasers. Students will use optical instruments } \\
\text { such as spectrum analyzers, power meters, and auto-collimators to align } \\
\text { and measure basic laser properties. }\end{array}$ \\
\hline 7 & $\begin{array}{l}\text { Fiber Optics } \\
(\text { EOPT } 240 *)\end{array}$ & $\begin{array}{l}\text { Covers basic concepts in fiber optics such as dispersion, attenuation, } \\
\text { single mode and multimode propagation. Fiber optics test equipment } \\
\text { such as optical spectrum analyzer and optical power meter are discussed } \\
\text { and investigated. Sources, detectors, optical amplifiers and passive fiber } \\
\text { components are covered. }\end{array}$ \\
\hline 8 & $\begin{array}{l}\text { High Vacuum } \\
\text { Technology } \\
(\text { EOPT 250*) }\end{array}$ & $\begin{array}{l}\text { Presents the properties of gases and the concepts of fluid flow and } \\
\text { pumping. Many different kinds of vacuum pumps are discussed in } \\
\text { detail. The concept of measuring a vacuum is introduced through the } \\
\text { discussion of vacuum gauges and gas analyzers. Covers the techniques } \\
\text { of leak detection and thin film deposition. }\end{array}$ \\
\hline 9 & $\begin{array}{l}\text { Industrial } \\
\text { Applications } \\
\text { of Lasers } \\
\text { (EOPT } 260 *)\end{array}$ & $\begin{array}{l}\text { The first half of the course introduces the student to semiconductors and } \\
\text { solid-state lasers and associated technologies. The student will learn } \\
\text { how to operate and perform basic maintenance on these lasers, as well } \\
\text { as how to measure basic laser parameters. The student will then apply } \\
\text { this knowledge, along with that developed in EOPT } 220 \text {, toward laser } \\
\text { applications in manufacturing, defense, medicine, and other important } \\
\text { areas. The course assumes a background in basic laser theory, basic } \\
\text { electronics, and wave optics as well as knowledge of algebra and right- } \\
\text { angle trigonometry. }\end{array}$ \\
\hline
\end{tabular}

*The A.S.E.O. degree requires 2 of the following 3 courses: EOPT 240, EOPT 250 and EOPT 260. 
The suggested coursework offered during the first two years which will satisfy the A.A.S.E.O. Degree requirements is outlined below.

\begin{tabular}{llr} 
Semester I & & Credits \\
\hline PHYS 100 & Prelude to Physics & 3 \\
PHYS 115 & Physics I for Electro-Optics & 3 \\
COSC 101 & Microbased Computer Literacy & \\
or & & 3 \\
COSC 201 & Internet and Multimedia & 3 \\
EOPT 250 & High Vacuum Technology & 3 \\
EOPT 110 & Geometric Optics & 15 \\
& Sub-total & \\
Semester II & & 4 \\
ENGL 101 & College Writing & 3 \\
PHYS 116 & Physics II for Electro-Optics & $3-4$ \\
MATH 110 & Elementary Functions & 3 \\
or & & 4 \\
MATH 121 & Calculus I & $17-18$ \\
EOPT 120 & Wave Optics & \\
EOPT 125 & Introduction to Electronics & 3 \\
Semester III & Sub-total & 4 \\
\hline & Humanities Elective & 3 \\
CHEM 111 & General Chemistry I & 3 \\
EOPT 105 & Computer Interfacing in E-O & 3 \\
MGMT 234 & Introduction to Quality Control & 16 \\
EOPT 220 & Introduction to Lasers &
\end{tabular}

$\underline{\text { Semester IV }}$

EOPT 210

Social Science

3

Detection and Measurement $\quad 3$

SAFE 145

EOPT 240

Workplace Safety

3

Fiber Optics

EOPT 260

Industrial Applications of Lasers

Sub-total

The program consists of a total of 63-64 credits.

Due to the rapid emergence and interdisciplinary nature of the field, teaching strategies in IUP's Electro-Optics Program give highest priority to activities that encourage creativity, critical thinking, and problem-solving skills. Furthermore, since the program is introduced early during the freshman and sophomore years, emphasis is placed on concept development and qualitative analysis rather than mathematical derivations. The focus has been purposely diverted from the study of "facts," which has been the pattern for physics textbooks for a long period of time, to problem-solving skills. In addition, emphasis is placed on synergy among different Electro-Optics core courses, reinforcing students' knowledge in this new field of study. 


\section{Hands-on Practical Skills Training}

Due to the necessity of hands-on experience to succeed in the Photonics Industry, each Electro-Optics core course in IUP's program consists of hands-on lab experiments in addition to lectures. Since IUP is on a semester system, the 3-hour lab experiments are arranged once per week during each 15-week semester.

\section{A. Equipment}

Through these labs, students learn vital hands-on skills utilizing state-of-the-art Electro-Optics equipment and optical alignment techniques. Some of the instruments used by students in IUP's Electro-Optics Program are listed in Table 2.

Table 2: Equipment used in select Electro-Optics lab experiments

\begin{tabular}{|c|c|}
\hline Course & Equipment/Software \\
\hline $\begin{array}{l}\text { Geometrical } \\
\text { Optics } \\
\text { (EOPT 110) }\end{array}$ & $\begin{array}{l}\text { - Prism spectroscope } \\
\text { - Optical power meter } \\
\text { - Microscope and traveling microscope } \\
\text { - Telescope and beam collimator/expander } \\
\text { - Projector } \\
\text { - ZEMAX Optical design software } \\
\end{array}$ \\
\hline $\begin{array}{l}\text { Introduction to } \\
\text { Lasers } \\
\text { (EOPT 220) } \\
\text { and } \\
\text { Industrial } \\
\text { Applications } \\
\text { of Lasers } \\
\text { (EOPT 260) }\end{array}$ & $\begin{array}{l}\text { - He-Ne lasers: red, yellow and green } \\
\text { - Argon laser with multi-wavelength output } \\
\text { - Acousto-Optic and Electro-Optic modulators } \\
\text { - Flashlamp pumped Q-switched Nd:YAG laser } \\
\text { - } 20 \mathrm{~W} \text { Fiber coupled semiconductor laser and power supply } \\
\text { - Solid state green laser from a diode pumped } \mathrm{Nd}: \mathrm{YVO}_{4} \text { laser with intra-cavity } \\
\text { frequency doubling } \\
\text { - Solid state blue laser from a diode pumped Nd:YAG with intra-cavity frequency } \\
\text { doubling } \\
\text { - Q-switched, frequency tripled, diode pumped } \mathrm{Nd}: \mathrm{YVO}_{4} \text { laser } \\
\text { - 3D laser imaging system }\end{array}$ \\
\hline $\begin{array}{l}\text { Fiber Optics } \\
\text { (EOPT 240) }\end{array}$ & $\begin{array}{l}\text { - Tunable light source and handhold power meter at } 1550 \mathrm{~nm} \\
\text { - Optical spectrum analyzers (OSA) } \\
\text { - Optical fiber fusion splicer and fiber cleaver } \\
\text { - Fiber Bragg gratings and other fiber optic components } \\
\end{array}$ \\
\hline $\begin{array}{l}\text { High Vacuum } \\
\text { Technology } \\
\text { (EOPT 250) }\end{array}$ & $\begin{array}{l}\text { - Vacuum pumps (rotary, diffusion, turbo and cryo) } \\
\text { - Vacuum gauges } \\
\text { - Thermal evaporator and Electron-beam evaporator } \\
\text { - Vacuum leak detector } \\
\text { - Residual pressure analyzer } \\
\text { - } 1000 \text { grade cleanroom }\end{array}$ \\
\hline
\end{tabular}

\section{B. Lab Experiments}

The laboratory experiments developed for the Geometric Optics course (EOPT 110) are listed in Table 3. Students attend two hours of lecture and one three-hour lab per week. The semester course runs for 15 weeks, plus one week for the final exam. For each lab experiment, students use a lab manual developed by IUP's Electro-Optics faculty. Students are responsible for building the experiment without any preliminary setup. They select appropriate equipment available in the lab such as optical components (mounts and holders, etc.), light sources (lasers, light bulbs, etc.) and measurement instruments (optical power meter, etc.) to complete the experiment After completing the lab, each student has to submit a formal lab report, documenting the objectives, basic theory, procedure, data collected, results, discussion, and conclusions. 
Table 3: Geometric Optics (EOPT 110) Lab Experiments

\begin{tabular}{|c|c|c|}
\hline$L a b$ & Title of Lab & Objective \\
\hline 1 & The law of reflection & $\begin{array}{l}\text { - To study the law of reflection } \\
\text { - To measure the incident and reflected angles made by plane and } \\
\text { spherical surfaces }\end{array}$ \\
\hline 2 & The law of refraction & $\begin{array}{l}\text { - To study the law of refraction } \\
\text { - To measure the incident and refracted angles and determine the } \\
\text { refractive index }\end{array}$ \\
\hline 3 & $\begin{array}{l}\text { Prism spectroscopy and } \\
\text { refractive index measurement }\end{array}$ & $\begin{array}{l}\text { - To learn how to use a prism spectroscope } \\
\text { - To measure the apex angle of a prism } \\
\text { - To determine the refractive index of a prism }\end{array}$ \\
\hline 4 & $\begin{array}{l}\text { Measurement of beam spot } \\
\text { size, power and photometric } \\
\text { light flux }\end{array}$ & $\begin{array}{l}\text { - To learn how to use power meter } \\
\text { - To measure the laser beam spot size and divergence angle } \\
\text { - To estimate the refractive index using the reflection method }\end{array}$ \\
\hline 5 & $\begin{array}{l}\text { Image formation from } \\
\text { spherical mirrors }\end{array}$ & $\begin{array}{l}\text { - To determine focal length and the radius of curvature of a spherical } \\
\text { mirror } \\
\text { - To study the image formed by a spherical mirror }\end{array}$ \\
\hline 6 & $\begin{array}{l}\text { Image formation with } \\
\text { cylindrical mirrors and lenses }\end{array}$ & $\begin{array}{l}\text { - To learn how to use a cylindrical optical component } \\
\text { - To study the properties of image formation with cylindrical mirrors } \\
\text { and lenses }\end{array}$ \\
\hline 7 & $\begin{array}{l}\text { Spherical lenses - Images } \\
\text { and object relationship, } \\
\text { aberrations }\end{array}$ & $\begin{array}{l}\text { - To understand the image formation by spherical lenses } \\
\text { - To measure the focal length of a lens } \\
\text { - To understand lens aberrations } \\
\text { - To study the depth of field } \\
\text { - To measure the radius of a spherical surface using a spherometer }\end{array}$ \\
\hline 8 & Thin lens combination & $\begin{array}{l}\text { - To study experimentally the image formed by multiple thin lenses in } \\
\text { series }\end{array}$ \\
\hline 9 & The projector and magnifier & - To understand the principle of a projector and a magnifier \\
\hline 10 & $\begin{array}{l}\text { The telescopes and beam } \\
\text { collimators }\end{array}$ & $\begin{array}{l}\text { - To understand the principle of telescopes } \\
\text { - To measure the magnification of a telescope } \\
\text { - To set up astronomical and Galilean beam expanding collimators } \\
\text { - To compare the laser beam property before and after the beam } \\
\text { collimator }\end{array}$ \\
\hline 11 & $\begin{array}{l}\text { The compound microscope } \\
\text { and its use in measuring } \\
\text { refractive index }\end{array}$ & $\begin{array}{l}\text { - To set up a simple compound microscope } \\
\text { - To measure the overall magnification of a compound microscope } \\
\text { - Learn how to measure the refractive index using a traveling } \\
\text { microscope }\end{array}$ \\
\hline 12 & Field stops and apertures & $\begin{array}{l}\text { - To understand the concepts of the field stop and aperture stop } \\
\text { - To determine the entrance and exit pupils and aperture stop for the } \\
\text { system of two lenses with an intermediate stop }\end{array}$ \\
\hline 13 & $\begin{array}{l}\text { Experimental study of a thick } \\
\text { lens system matrix }\end{array}$ & $\begin{array}{l}\text { - To understand the definition and learn how to use the basic matrices. } \\
\text { - To verify the basic matrices for a thick lens experimentally }\end{array}$ \\
\hline 14 & $\begin{array}{l}\text { Optical design using ZEMAX } \\
\text { software }\end{array}$ & $\begin{array}{l}\text { To learn how to enter data into ZEMAX, set the system aperture, } \\
\text { lens units, and wavelength range and then optimize the design } \\
\text { - To learn how to use ray fan plots, spot diagrams and other diagnostic } \\
\text { tools to evaluate the performance of the design } \\
\text { To design singlet and doublet lenses }\end{array}$ \\
\hline
\end{tabular}


In general, the Electro-Optics labs developed for this unique program emphasize general instrumentation and equipment used currently in the Electro-Optics Industry: basic optical alignment skills, experimental methods, and problem-solving skills. Table 3 also lists the objectives for each lab, reinforcing the basic theory introduced during class lecture. Students gain experience using numerous types of optical components. Furthermore, the basic alignment skills of these optical components are learned using both optical rails and optical breadboards.

\section{Industry Collaborations}

The collaborations among IUP, Lenape, and the Electro-Optics corporations have been strengthened by the creation of the $2+2+2$ Steering Committee. The thirty-nine members represent the major Photonics companies in the region. The members are very supportive, and almost 100 percent of the membership meets twice a year to be actively involved with this unique program.

\section{Outreach Efforts}

Electro-Optics is a fairly new industry to Pennsylvania and, as such, it is ahead of the curve. Therefore, emphasis had to be placed on promoting awareness of this new initiative to students, parents, and the community in order to educate them on the various career opportunities created by this emerging industry.

To increase awareness in Electro-Optics, activities have been focused on a variety of areas: outreach activities geared toward middle- and high-school students, the establishment of parent information sessions, workshops for professional development for teachers and guidance counselors, and an aggressive media campaign.

\section{A. Outreach to Area Students}

The program's faculty and staff have interacted with 1,768 students from 1/1/2006 to 4/27/2007 throughout Armstrong, Allegheny, Butler, Indiana, and Westmoreland counties. The interactions included visits to the classrooms, career fairs, and field trips designed for the students to visit the campus. A survey is administered to the students after each visit. The information gleaned from the surveys is very informative. Approximately $50 \%$ of the students expressed an interest in Electro-Optics after the interaction. Many of the students who expressed an interest in the field after the interaction did not have previous knowledge of Photonics.

Primarily, outreach activities have included: the Electro-Optics Science Experience at Northpointe Regional Campus, classroom presentations, and the Electro-Optics Summer Camp. During classroom presentations, students learn about the emerging field of Electro-Optics through portable hands-on activities such as: diffraction grating glasses, night-vision scopes, and polariscopes. These experiences allow students to view stress and strain points within various transparent objects through crossed polarizers. The primary focus, however, is to promote the hightech careers in the Electro-Optics Industry, as well as the necessity for preparation in mathematics and science.

The "Electro-Optics Science Experience" takes place in the Electro-Optics state-of-the-art labs at the IUP Northpointe Campus. It is comprised of an introductory session, highlighting an overview of the field of ElectroOptics, an employment outlook and Optical Jeopardy session; as well as a laboratory session, where the students gain a better understanding of such concepts as polarization, open-space communication, optical illusions, holography, laser diffraction, and fiber-optics through hands-on activities. Forty students can be accommodated at each visit. Funding from the grant pays for the busses and lunch for area students. The school districts would not be able to send students on these field trips if they had to pay for the busses.

Last year's Summer Camp was held from July 31-August 4, 2006. IUP at Northpointe partnered with the EOC to offer an exciting summer camp for high-school students. Eighteen students from local high schools participated in this week-long event which was designed to expose students to the new, high-tech career field of Electro-Optics and the educational opportunities available in this field. This year's Summer Camp is scheduled for June 18-22, 2007. The event will provide lessons and activities in wave optics, fiber-optics, electronics, and nanotechnology. 
These outreach activities have resulted in the creation of the first $2+2+2$ Integrated Workforce Leadership Program in Electro-Optics at Lenape. Eighteen students began coursework in the prototype program in Fall 2006ten juniors and eight seniors. The Outreach/Career Coordinator has met individually with these students throughout the 2006-2007 academic year to discuss courses, future goals, and potential admission to IUP's Electro-Optics Program, creating an educational pipeline.

\section{B. Parent Information Session}

Area parents were invited to attend an Electro-Optics Information Session on March 13, 2007, at the IUP Northpointe Regional Campus. Thirty-five people attended and received information on Electro-Optics and its importance to Armstrong County. They also received information on careers in the field and educational programs. They participated in hands-on activities to gain insight into the nature of this emerging industry. The outreach activities, designed to introduce parents to this new field, are essential as they bring the knowledge of Photonics into the homes and reinforce the opportunities available to this area.

\section{Professional Development Opportunities for Teachers}

IUP also provides professional development activities such as workshops for local high school administrators and instructors. Area guidance counselors, teachers, and affiliated educational program leaders were invited to participate in IUP's 2+2+2 Electro-Optics Workshop for Teachers and Guidance Counselors. Participants took part in hands-on Electro-Optics activities that could be used in their classroom. They also received activities with a corresponding curriculum guide to take back to their schools. Program speakers discussed the efforts and history of program development, an overview of the $2+2+2$ Workforce Leadership Development Program in Electro-Optics, and educational curriculum and career opportunities.

\section{Media Campaign}

Electro-Optics students from IUP and Lenape have taken an active role in recruiting other students into the program. They participated in the development of a television commercial which advertised the program to area students. The commercial aired on ESPN, ESPN 2, MTV, VH-1, SPIKE, and TNT, stations that target the highschool/teen population. The commercial can be viewed on our website: www.iup.edu/armstrong/222/index.shtm. The goal was to expand awareness of the Electro-Optics field into the homes.

In addition, a roadside billboard advertising the $2+2+2$ Electro-Optics Program partnership was developed by IUP and was displayed on Route 28 near Exit 18, the IUP Northpointe exit. Over 7,000 vehicles drive past this site every morning and evening, providing program visibility.

\section{Challenges}

Highly technical programs tend to be ahead of the curve. Consequently, the workforce is not up to speed. ElectroOptics emerged into Armstrong County a number of years ago, but the community is not aware of the career opportunities. Electro-Optics is not a subject in our schools at any level. Our most difficult challenge is the recruitment of academically prepared students, as these students are headed for four-year degree programs in computer science or engineering. When students think of technical programs, they do not think that they need to have knowledge of math and science. However, math and science preparation is a necessity for these types of programs. Finding academically prepared students is one of the challenges that this program faces.

Highly-technical programs also tend to be costly. A used Yag laser costs $\$ 30,000$, while a used Tunable laser costs $\$ 90,000$. Educational institutions do not have money for high-tech programs, especially if they have low enrollments. 